NEW VIEWPOINTS ON

THE SPANISH COLONIZATION OF AMERICA 



\section{Nerw Viewpoints on}

\section{THE}

\section{SPANISH GOLONIZATION $\mathrm{OF}$}

AMERICA

By

Silvio Zavala

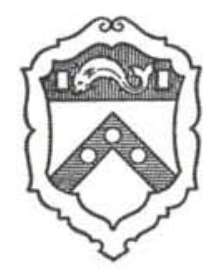

Philadelphia

UNIVERSITY OF PENNSYLVANIA PRESS

London: Humphrey Milford: Oxford University Press

1943 
Copyright 1943

\section{UNIVERSITY OF PENNSYLVANIA PRESS}

Manufactured in the United States of America 